\title{
Supervision and Control of The Government Internal Supervisory Apparatus in The Implementation of Regional Autonomy
}

\author{
Engkus ${ }^{1}$, Cecep Wahyu Hoerudin ${ }^{2}$, Dedeng Yusuf Maolani ${ }^{3}$ \\ 1,2,3UIN Sunan Gunung Djati Bandung, Indonesia \\ email: engkus@uinsgd.ac.id
}

\begin{abstract}
The main problem of this regional autonomy research is the low competence of human resources in the New Autonomous Region of Pangandaran Regency, which is caused by its suboptimal implementation. The purpose of this study is to describe the implementation of regional autonomy and its impact. The method used is a qualitative approach with observation, interview and library study techniques. This study concludes that the implementation of regional autonomy in Pangandaran is not yet optimal. The positive impact of regional autonomy can increase the efficiency and responsiveness of government in public services with public preference, and arouse the spirit of competition and innovation among local governments. The negative impact, the quality of public services is low, due to the transfer of authority which is often misunderstood or misused so that adequate and formal supervision and control is needed both formally and informally as well as synergy between local, provincial and central governments.
\end{abstract}

Keywords: Human Resources, Supervision, Inspectorate

\section{Introduction}

The regional government is faced with various challenges and obstacles in the implementation of regional autonomy, but there are two important institutions of the regional government, namely (1) the Regional House of Representatives, (2) the Regent and the regional apparatus, which based on Pangandaran District Regulation Number 31 of 2016 concerning Formation and Organization of the Regional Apparatus of the District of Pangandaran, in it the Inspectorate of Pangandaran Regency was formed as the Government Internal Control Apparatus which functions to oversee the implementation of regional autonomy.

Autonomy broadly means the decentralization of authority and power to certain regions to manage and use resources optimally. To avoid deviation of the oversight function by the Regional House of Representatives is very important. Strengthening control functions can be generated by optimizing the function and role of the Regional Representative Council as a balance force for the region exclusively (Mardiasmo, 2004). The following data and facts from the evaluation of the ministry of the interior are not yet optimal and public complaints indicate that the performance of the services, the control function is not optimal, and complaints still occur (no zero complaint). 


\section{Diagram 1.}

DOB Evaluation Results for 2017

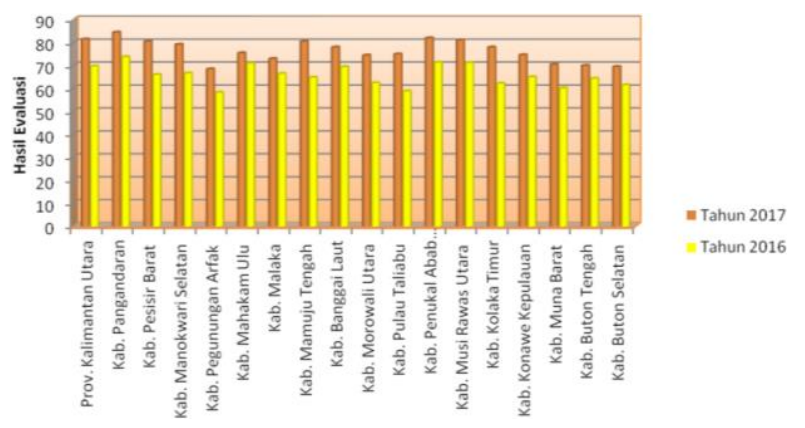

Source: Directorate General of Regional Autonomy at the Ministry of Home Affairs, 2018

Waste pollution in rivers still occurs frequently, The Citonjong River is polluted by a coconut processing factory, the water is black and the smell has penetrated the people's wells (https://www.facebook.com/beritapangandarannews/videos/484739102275894/)

PangandaranNews,(harapanrakyat.com), - Residents of Paledah Hamlet, Paledah Village, Padaherang District crave a proper waste disposal site. This is because in addition to a place that does not exist, coupled with a lack of community awareness of maintaining cleanliness. One resident, Ahmad, said that the absence of a landfill in his village made residents forced to dump garbage into the water channel and also to the Ciseel River (https://www.harapanrakyat.com/2019/08/warga-pangandaran-minta-tempat-

pembuangan-sahah/

To produce or implement policies is not easy, Hogerwerf in Wahab, (2004) asserted "to succeed government policies, good implementation is needed. The definition of policy implementation is an effort to achieve certain goals by using selected sources. Policy in the management context is given by (Nugroho, 2011: 665): "Public policy is management, which increases reasoning skills that public policy must be controlled. So, instead of using the phrase policy evaluation I would prefer to use the technical term controlling policy only. Policy control is divided by 3 (1) policy monitoring or policy control. (2) policy evaluation. (3) policy feedback. In order to realize government activities, management is needed. Furthermore, (Silalahi, 2013: 174), provides an understanding that: "Planning is a decision line activity, human resources, materials used or needed, and operational activities, while control refers to activities to realize objections along with effective sources are not deviating from planning through the implementation of the control function, can be recognized early on. whether the goal is accompanied by planning or irregularity due to irregularities.

However, any gaps that occur between expectations and implementation in every unit of the entire organization will be easier to resolve if known earlier than waiting for serious deviations to occur. Through these control measures will provide fast information to further take steps to correct irregularities that occur. Control activities are needed primarily to answer the question whether the activity is running or not.

\section{Research methods}


This study uses a qualitative research methodology approach that is inferential, namely research methods for the actual problems that occur in people's lives (Singarimbun, 1994: 5). Data collection techniques are used as follows: (1) Literature study begins by reviewing text books related to the journal material to be written. Including understanding the actual media and electronics with relevant journals made. (2) observation technique is a direct observation of the object needed and related to the problem to be discussed. (3) Interview or quesionare technique is to hold discussions with related parties such as the Pangandaran Regency Regional Representative Council, the Pangandaran Regency inspector / subordinate, and those related to the object being studied. (4) Historically documented, this technique is used to obtain material related to theories that can be used as a basis for discussing, understanding and explaining the problem and the object being investigated. This technique is also used for comparison materials. (Tutik Rachmawati, 2016: 1).

\section{Research and Discussion}

Control is generally defined as the main activity in management to try so that the work will be in accordance with the expected planning. Basically, control occurs following the following patterns: (1) setting standards on controls, (2) measuring work results as soon as possible, (3) comparing work results with pre-determined standards, (4) taking corrective action. In implementation policy, control is generally defined as supervision. Whereas supervision (control) is often interpreted as an effort to control.Accompanied by continuity actions with the aim of sustainable activities will be able to achieve the targets according to specified. Thus management has a broader scope than controlling. supervision includes: (1) controlling, whether preventive or repressive; step (2) guidance / instructions from the leadership (3) direct observation observations in place (4) collect and analyze all information related to the relevant project activities and (5) determine policies. So in the assumption of supervision and control in the implementation of government actually comes from the same word controlling which can be interpreted as the main activities in management accompanied by follow-up with the aim that the implementation of government takes place efficiently, effectively and ethically to achieve targets in accordance with established plans with the desired results. In the concept of regional autonomy, supervision of the implementation of regional government is carried out by the central government based on applicable laws and regulations (Law No. 32 of 2004). supervision, then the objectives to be achieved can be seen by guiding a predetermined plan. by the government. Thus, supervision is very important in carrying out the work and tasks of the government, so that supervision is carried out with the intent to (1) know how the work works or not (2) correct the mistakes made by staff and take action to prevent them from happening again in the future (3) know the implementation of work in accordance with the program that has been planned or not. Regarding the objectives of supervision, Silalahi (2013: 175) states: "Supervision is intended to prevent irregularities in the implementation of activities or work and at the same time take corrective action if deviations have occurred from what has been planned.Thus supervision activities must ensure that the implementation of the plan in accordance with those specified in the plan.Because supervision is intended to achieve 
objectives in accordance with or deviate from the specified plan, supervision activities contain activities tan who provides guidance or instructions. "The role of the central government, Wicaksono, (2014: 95), believes that:" ... the administration of the central government must function purely as an external advisor, inspector and does not have a strategic role in local authority.

The results of the study show that by emphasizing repressive supervision (for example in the procedure for drafting local regulations), it has a negative aspect, so that there are many disadvantages to the community, besides the lack of guaranteed legal certainty. This is evidenced by the many regional regulations that were returned and canceled by the Central Government because it harmed the community. In its implementation, the Central Government did not immediately cancel the laws deemed contrary to higher laws and public interests but returned them first to the regional governments for revision. or revoked. Thus the Government has expanded the procedure / mechanism of cancellation regulated in Article 145 of Law Number 32 of 2004. In addition, for laws that are revoked, in fact, no regions have yet used the objection procedure either for the Central Government or to the Supreme Court. In other words, up to now the provisions contained in Article 145 of Law Number 32 Year 2004 have not been optimally applied.

On the other hand, several parties have shown that the various supervisory efforts that have been carried out so far have yielded good results, in the sense of being able to provide caution and discipline to the rules in force. In addition, only the optimization and seriousness of the supervisory apparatus at all levels / strata is needed in accordance with their duties, functions and responsibilities. This statement contradicts the reality on the ground because most regent feel disruptive comfort in the implementation of local government because the supervision process is sometimes incorrect.

Complaints were conveyed that the supervision was often carried out sequentially and tended to overlap. On the other hand, the results and benefits of supervision have not been felt.So far, the supervision carried out in the regional government has been characterized by stagnant phenomena from time to time, for example (1) supervision conducted by the Regional Parliament of Pangandaran Regency tends to be technical supervision; which must remain within the corridors of applicable laws and regulations, namely higher law and public interest; (2) supervision conducted by the Government Internal Supervisory Apparatus tends to overlap; which among others are caused by differences in perception so as to be urgent, and immediately resolved through integrated supervision which is coordinated in accordance with Law number 32 of 2004; and (3) oversight carried out by the Government Internal Supervisory Apparatus does not appear to be carried out on all government programs, regional government and other government affairs.

To overcome this problem, the Government should carry out integrated supervision based on (1) synergy of supervision as a necessity for the profession of the Government Internal Supervisory Apparatus to be developed and coordinated with Law Enforcement Officials to accelerate the eradication of Collusion Corruption and Nepotism Corruption; (2) socialization of supervision policies to all parties so that the bureaucracy and the community 
can run professionally and proportionally; (3) to increase the technical and intellectual capacity of the supervisors in accordance with the professional demands and needs of each Government's Internal Supervisory Agency; (4) coordination of supervision starts from the planning, implementation, reporting and follow-up of the results of supervision so that supervision activities have preventive power, barrier strength and cause deterrent effect for the perpetrators of irregularities in carrying out their duties and management of the resources for which they are responsible; (5) coordinating community monitoring and monitoring results of the Government Internal Supervisory Apparatus with elements related to the regional government wisely so that all parties are motivated towards the creation of good and clean governance; (6) conduct a special inspection and / or simultane'ous examination of issues that are of concern to the government and / or the community in administrative and / or regional government matters that have not been accommodated in the regular supervision work program.

Based on research results that the supervision of the Pangandaran Regional Representative Council in encouraging the inspectorate towards the implementation of regional autonomy does not yet have optimal implications, although based on the 2017 Financial and Development Supervisory Agency assessment report that in 2015 the Government Capacity of the Internal Supervisory Apparatus / Inspectorate of the Pangandaran Regency received a score of "Level 1 "Button. However, on the other hand there are research findings that, after regional expansion in Pangandaran District in 2012 various problems related to public services were found such as the magnitude of service discrimination, lack of service certainty, and low levels of public satisfaction with public services. . (Ramadan, S, 2016). (http://repository.unpas.ac.id/13448/). So the authors add to the belief that the central government needs to immediately restructure the functions of other institutions, for example the supervision of the district inspectorate both in organizational and administrative aspects through (1) strengthening the District Inspectorate in accordance with the applicable provisions as an internal auditor of the local government that encourages good governance; (2) division of objectives and priorities of regular routine audits based on a phased annual performance indicator approach to reduce audit duplication or overlap; and (3) strengthen the capacity of the Government's Internal Oversight Apparatus to improve the quality, competency, and independence of the inspectorate as well as the education and training / skills of auditors, and the importance of designing inspectorate organizations that are not part of the organizational structure of local government, but are integrated with the Financial Supervisory Board or the supervisory agency the other.

The authors' findings of another type of supervision that are often carried out by local governments are Internal Control and External Monitoring. Internal control is carried out based on the dimensions of monitoring, evaluation and reporting carried out by the apparatus in the organization itself (Engkus,2018). Basically, supervision must be carried out by the leader himself. But in practice this is not always possible. Therefore, every leader in the organization is basically obliged to help the top leadership to carry out functional supervision in accordance with their respective fields of work. Whereas External 
Supervision is supervision carried out by officers from outside the organization itself. Such as oversight in the financial sector by the Supreme Audit Board or the Financial and Development Supervisory Agency.

Other research findings, supervision based on the classification of supervision and based on the field of supervision: (a) budget control; (b) cost control; (c) monitor inventory control; (d) production control; (e) supervision of the amount of work (quality control). However, the supervisory process is important in carrying out organizational activities, therefore every leader must perform the supervisory function as a management function which is a manifestation of the leadership function of his subordinates, which in turn manifests an increase in effectiveness, efficiency, and rationality, as well as regularity in achieving the goals set .

Supervision by the leadership of the organization will have implications for the implementation of the plan, if supervision is carried out properly, and the objectives can be known to be achieved properly or not after the supervision process is carried out. Thus the role of supervision is very important for the implementation of the plan. The form of Supervision on the Implementation of Local Government is based on the object of supervision, namely: supervision of regional policies in Pangandaran Regency. Policy monitoring is carried out in a repressive manner. According to Government Regulation Number 20 of 2001, Repressive Control is supervision made on policies that have been established by the regions in the form of Regional Regulations, Decrees of Regional Heads, Decrees of Regional Representatives Council or Decrees of the leadership of Regional Representatives Council in the context of implementing Regional Government. The legal and policy products that are the object of supervision are: (a) regional regulations of Pangandaran Regency; (b) The decision of the regent of Pangandaran; (c) Decisions of the Pangandaran Regency Regional Representative Council; and (d) Decision of the Chairperson of the Regional Representative Council of Pangandaran Regency. Parties that can oversee Pangandaran Regency and policy products are: (a) the Regional Representative Council of Pangandaran Regency, (b) the Minister of Home Affairs of the Republic of Indonesia, and (c) the Governor of West Java. Supervision of legal products is needed to ensure that legal products such as local law do not conflict with the principles of the unitary state and national law. Supervision also serves to protect people from the arbitrariness of gratuity. Forms of regional supervision: Oversight by the Regional Parliament of Pangandaran. The authority of the Pangandaran Regional Representative Council is to supervise legal products as mentioned in Article 18 of Law number 22 of 1999 without further detailing their authority and authority. Parliamentary oversight of legal and policy products is not accompanied by law enforcement powers, such as cancellations. The only power of the Regional House of Representatives in this case is to hold the Bupati accountable and propose the Bupati's dismissal from the President. This can make policy oversight by regional parliaments less effective.

Oversight by the Central Government in this case the Minister of the Interior can carry out repressive policy oversight assisted by a team whose members consist of ministries or 
non-ministerial government agencies and other elements as needed. Unlike the oversight by the legislature in the Regency or Province, the Minister of Home Affairs has the right to make decisions on Regional Regulations, Regents of the Regents, Regulations of the legislature in the province or regency and Decree of the leadership after giving advice, considerations, corrections and improvements. The governor can exercise supervision if he is granted a delegation of authority from the Minister of the Interior.

In the case of the implementation of regional autonomy, the Regional Parliament of Pangandaran Regency has the authority to oversee the implementation of: (a) Regional Regulation of the Pangandaran Regency; (b) Decision of the Regent of Pangandaran; (c) Other Regulations; and (d) International Cooperation.

To carry out its supervisory function, the Regional Parliament of Pangandaran Regency in carrying out its duties has the right to ask state officials, government officials, or citizens to provide information about something that needs to be addressed in the interests of the state, nation, government and development.

Internal Control Regional government as a whole is the responsibility of the Regent. Supervision is carried out by a Board or Supervisory Board which is now generally called the District Inspectorate. The Pangandaran Regency Inspectorate is a technical institution and functions as a supporting element of the regional government in the field of supervision.

In general, regional government internal supervision includes: (a) implementation of local government; and (b) Local government apparatus performance.

Implementation of Oversight of regional autonomy by the central government is carried out by two institutions: (1) Oversight by the Minister of the Interior; (2) Supervision by the Minister or Head of Non-Ministerial Government Institutions. Supervision by the Minister of the Interior includes: (a) Implementation of local government; (b) Performance of regional autonomy; (c) Performing deconcentration and assistance tasks in their fields; and (d) Effectiveness of the implementation of regional government implementation guidelines in accordance with their duties. While Supervision by the Minister or Head of Non-Ministerial Government Institutions is carried out under the coordination of the Minister of Home Affairs, including: (1) implementation of the task of deconcentration and assistance in their fields; (2) the effectiveness of the implementation of guidelines for the implementation of regional government in accordance with their fields of work.This form of supervision is carried out by: (1) periodic inspection, insured inspection or integrated inspection; (2) periodic and / or occasional test reports from units or work units; (3) investigation of the truth of reports about indications of corruption, collusion and nepotism; and (4) assessment of the benefits and success of policies, implementation of programs, projects and activities.

The central government under the coordination of the Minister of the Interior can impose sanctions on the district /municipality/ provincial government and / or its officials who refuse implementation, as well as follow-up on the results of regulatory oversight. 
The implementation of community surveillance can be carried out by the community as individuals, groups, or organizations by: (1) providing information about indications of corruption, collusion or nepotism within the local government or the Regional People's Representative Council in the district; (2) submission of opinions and suggestions regarding improvements, both preventive and repressive problems. In other words, this form of supervision is in the form of public participation: as revealed by Wibawa and Muluk (2009: 360):"By understanding the position of the role of the local elite as the influence and support of the central government as an obstacle, efforts to increase community participation in local government must be done in two ways. The first way to make changes to the lever factor is the role of the local elite because the lever has special features with small changes alone can bring about major changes to the system. The second way is to reduce the limits of participation contained in the constraints of central government support, as expressed by Senge: "do not encourage growth; remove factors that limit growth. "Senge's suggestion means that to improve the performance of a system, the steps that must be taken are not to suppress growth or strengthen the circle but instead by eliminating factors that limit growth. These limiting factors are in loop balancing (counters).

The same thing was said by Purbani ( 2017): Government participation, transparency, and accountability are very important for; (1) to ensure that citizens can contribute, contribute and get good development services; (2) establishing checks and balances. Then the understanding of community empowerment was expressed by Widjaja, HAW (2007: 5):One important aspect of regional autonomy is community empowerment so that they can participate in the process of planning, implementing, mobilizing and overseeing local government management in the use of managerial resources and providing excellent services to the public. The Regional House of Representatives has the authority to oversee the implementation of the Regional Revenue and Expenditure Budget which is carried out through: hearings, working visits, special committees and the formation of work committees formed under the regulations of the Regional House of Representatives.

Regional Government Internal Oversight carried out by the Inspectorate of Pangandaran Regency which is the government internal supervisory apparatus has the main duties and functions to carry out financial supervision: (1) implementing regional revenue and expenditure budgets; (2) revenue from local and regional government companies; (3) procurement of goods / services and maintenance / transfer of goods/services; (4) settlement of compensation; (5) inventory and research on official wealth in local government.

The Government Internal Supervisory Apparatus is formed based on Government Regulation Number 60 of 2008 whose main tasks and functions are:(1) Audit, is the process of identifying problems, analysis, and evaluations conducted independently, objectively, and professionally based on audit standards, to assess the truth, accuracy, credibility, effectiveness, efficiency, and reliability of information on the implementation of the tasks and functions of government agencies.(2) Review is a review of evidence of an activity to ensure that the activity has been carried out in accordance with the provisions, standards, 
plans, or norms that have been set.(3) Evaluation is a series of activities comparing the results /achievements of an activity with established standards, plans, or norms, and determining the factors that influence the success or failure of an activity in achieving its objectives.(4) Monitoring is the process of evaluating the progress of a program / activity in achieving the stated goals.(5) Other supervision activities and activities that do not provide quality assurance, including consultation, outreach and assistance.

At the ideal level of implementation of autonomy, it means that all state activities in the regions are carried out by relevant local governments, but in reality, at the implementation level there are still many deviations or misinterpretations or differences in perception between "das sollen" and "das sein".

Based on the fact that during the implementation of Law Number 22 Year 1999, and Law Number 25 Year 1999, up to Law Number 9 Year 2015, efforts were made to overcome this by formulating supervision from the center which was more clearly followed by training programs.In Law Number 32 of 2004, supervision can be seen in a number of ways, namely evaluation of the draft regional regulations and regional head regulations on regional revenue and expenditure budgets, as well as changes and accountability for regional revenues and implementation of the budget and draft Regional Regulations on matters the matter that has been mutually agreed upon and the draft governor's regulation concerning the elaboration of the Regional Revenue and Expenditure Budget before being determined by the Governor is conveyed to the Minister of the Interior for evaluation. The evaluation results are then submitted by the Minister of the Interior to the Governor.

Guidelines for the implementation of local government implemented by the central government. Coordination is carried out regularly at national, regional and provincial levels. Provision of guidelines and standards covering aspects of planning, implementation, management, funding, quality, control and supervision, guidance, supervision, and consultation are carried out regularly and sometimes, both thoroughly to all regions and to certain regions as needed.

Oversight of the implementation of local government is a process of activities aimed at ensuring that the local government runs according to plans and provisions of applicable laws. Supervision is carried out by the government related to the administration of government affairs and especially with regional regulations and regional head regulations. In terms of overseeing the draft regional regulations and regional regulations, the government does two ways: (1) supervision of the draft regional regulation (draft regulation) on the draft local regulation governing local taxes, user fees, regional budgets, before being approved by the regional head, first evaluated by The Minister of Home Affairs for the draft provincial regulations and by the governor the draft regional regulations. This mechanism is carried out so that the regulation of these things can achieve optimal use and results; (2) Supervision of all regional regulations beyond those included in point 1, i.e. each regional regulation must be submitted to the Minister of Home Affairs for the Province and the Governor for the Regency for clarification. Local regulations that are contrary to the 
public interest and higher regulations can be revoked in accordance with applicable mechanisms.

Meanwhile, to optimize the guidance and supervision function, the government can impose sanctions on local government administrators if irregularities and violations are found by local government officials.

Control of Regional Autonomy Implementation that Leaders have a big role in achieving organizational goals and developing their organizations to be able to survive the changes in the environment. Likewise with local government as an organization that also depends on the leadership of regional heads. The political will and competence (competence) of the regional head also determines whether the autonomy goal is achieved or not. In entering the round of regional autonomy, the regions inevitably have to try to explore the existing potential and encourage local governments to innovate and become more creative. However, currently in general, local governments are less innovative and creative in exploiting the existing potential. For example in managing resources. Many regions only implement programs like the previous program from year to year. There is no breakthrough program with new innovations that are more needed by the community. In fact, the environment continues to change so that their needs and demands are also higher.

The problems described above require an immediate solution for the purpose of regional autonomy in accordance with the provisions of the law. Solutions that can be offered include the qualifications of leaders or regional heads. Undeniably, the role of regional heads in determining the direction of regional development is very large. If there is no political will from the leadership, remedial efforts cannot be made. In addition, it requires regional heads who are capable in their fields, responsive, critical, have high creativity and innovation and a strong will to change the region for the better. Therefore, it is necessary to train political cadres by providing broad education and knowledge about local wisdom and the importance of regional competitiveness. So far, the regional heads have mostly come from political parties, so that the development of political cadres can be carried out by the related political parties and gives them responsibility to spawn cadre competencies.

Another aspect that needs to be improved is the involvement of the community from various groups, and the government giving as wide access as possible and not discriminating. Provides standard operating procedures for participating through social media (WA, SMS), call centers, post boxes, forums and there are institutions that handle them clearly and are socialized. Strengthening community participation also needs to be realized through optimization of Development Planning, from local participatory planning mechanisms at the village level, at the sub-district level to the District and provincial level. Although it cannot be denied, in fact, the formulation of policies that have been made in the planning mechanism at the village and sub-district level, when brought to the level of the district-level planning mechanism must clash with the work program that has also been prepared by each of the relevant agencies. In addition, reasons for budget limitations and ceilings are obstacles to realizing the policies formulated in the planning. Thus, agreements 
in planning must be made by the government, so that people will feel their presence and their participation is needed in the development process in regional autonomy.

This is in line with the opinion of Lele (2012):"Local participatory planning mechanisms have been widely criticized. Likewise, initiatives to implement citizen certificates and citizen report cards find opposition from local patrimonial elites.

The government must also be smart, creative and innovative in formulating policies, especially the ability to prioritize programs in the regions, so as not to cause social jealousy in the community itself.

Another solution in the recruitment of the state civil apparatus, so far, recruitment in the area is only through general selection, there is no other system that is adjusted between the formation and the educational background to suit the field of work. In addition, there are many corruption cases in areas where civil servants are recruited so that their performance is not based on expertise and there is no motivation to contribute to the region, which in the end the community does not get good service. The impact makes the local government stagnant, monotonous, in carrying out local programs. This condition builds weak regional competitiveness, and basically, the aspirations of regional freedom through regional autonomy are far from fire. Focus of this study is presented in Figure 1.

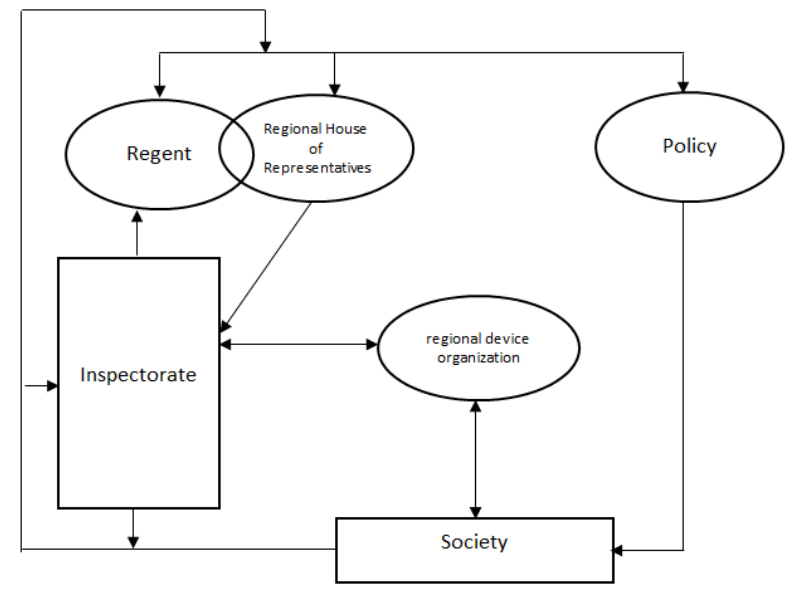

Figure 1.

Determinant Factors of Supervision in the Implementation of Regional Autonomy

\section{Conclusion}

Supervision conducted by the government internal supervisory apparatus/inspector of Pangandaran district is not optimal. this can be seen from several complaints from the public regarding public services that have been carried out by the offices. Increasing the competence of human resources, especially the official apparatus, is very important by increasing skills and responsiveness to problems that often occur, so that people feel the existence of new autonomous regions.

Based on the characteristics of the new autonomous region, the internal supervision apparatus of the government / inspectorate of Pangandaran Regency must report according 
to their functions and be responded to by the regent in accordance with the public interest. Technically operational, supervision and control (internal) based on 3 (three) dimensions: monitoring, evaluation and reporting.

\section{References}

1. Abdul Wahab, Solichin. (2004). Analisis Kebijakan Publik, Dari Formulasi Ke Implementasi Kebijakan Negara. Jakarta: Bumi Aksara.

2. Dunn, William. (2003). Pengantar Analisis Kebijakan Publik, Perterjemah Samudra Wibowo, Dkk. Yogyakarta: Gadjah Mada University Press.

3. Dess Gregory G. (2012). Strategic Management text and cases sixth edition. New York: The McGraw-Hill.

4. Islmamy, M Irfan. (2002). Prinsip-Prinsip Perumusan Kebijakan Negara. Jakarta: Bumi Aksara.

5. Kaho, Josef Riwu. (2010). Prospek Otonomi Daerah di Negara Republik Indonesia. Jakarta: Raja Grafindo Persada.

6. Mardiasmo. (2004). Otonomi dan Manajemen Keuangan Daerah. Yogyakarta: ANDI.

7. Nawawi, Ismail. (2009). Public Policy, Analisis, Strategi Advokasi Teori dan Praktek. Surabaya: PMN.

8. Nugroho, Riant. (2011). Public Policy. Jakarta: Gramedia.

9. Rachmawati, Tutik. (2016). Metode Pengumpulan Data Dalam Penelitian Kualitatif. Bandung: CPPMS FISIP UNPAR.

10. Wibawa Samodra dan Muluk MR Khairul. (2009). Administrasi Negara; Isu-isu Komtemporer. Yogyakarta: Graha Ilmu.

11. Singarimbun, Masri. (1994). Metode Penelitian Survai. Jakarta: LP3ES.

12. Siagian, Sondang P. (1990). Filsafat Administrasi. Jakarta: Haji Masagung.

13. Siagian, Sondang P. (2014). Administrasi Pembangunan Konsep,Dimensi, dan Strateginya. Jakarta: Bumi Aksara.

14. Silalahi, Ulbert. (2013). Asas-Asas Manajemen. Bandung: Refika Aditama.

15. Silalahi, Ulbert. (2013). Studi Tentang Administrasi: Konsep, Teori, dan Dimensi. Bandung: Sinar Baru Algensindo.

16. Situmorang, Victor Mdan Juhir, Jusuf. ( 1998). Aspek Hukum Pengawasan Melekat. Jakarta: Rineka Cipta.

17. Wicaksono, Kristian Widya. (2014). Telaahan Kritis Administrasi \& Manajemen Sektor Publik. Bandung: Gava Media.

18. Widjaja, HAW. (2007). Otonomi Daerah dan Daerah Otonom. Jakarta: Raja Grafindo Persada.

19. Widjaja, HAW. (2014). Otonomi Daerah dan Daerah Otonom. Jakarta: Raja Grafindo Persada. 
20. Alm,Aten and Bahn. (2001)."Can Indonesia Decentralise Successfully?Plan Problem, and Prospects",Bulletin of Indonesian Economic Studies,37(1),83-102.

21. Beaumont,E.(2001). "Policy and Administration: One More Time in Frying Pan", International Journal of Public Administrtion, 24(1)

22. Bjur,W.E. and Zomorrodian,A.(1986). "Towards Indigenous Theories of Administration:An International Perspective", International Review of Administration Sciences, 52(4), 504-509.

23. Denhardt, RB \& Denhardt,JV. (2000)."The New Public Service", Public Adinistration Review, 60(6),320-331.

24. Devas,N.(1997)."Indonesia: what do we mean by Decentralization?, Public Administration and Development, 17,351-367.

25. Engkus, E. (2013). Desentralisasi (Teori yang Baik dengan Praktek yang buruk), JISPO: Jurnal Ilmu Sosial dan Ilmu Polititik, (4), 1-16.

26. Engkus. (2018). Implementasi Undang-undang Perdagangan : Implikasinya Dalam Kebijakan Pengendalian Harga Kebutuhan Pokok Masyarakat. Jurnal LITIGASI 18 (1). pp. 1-144.UNPAS Bandung.

27. Engkus, E. (2017). The Influence Of organizational Behavior On Work Ethics Employees In Bandung Regency Goverment, IASET 1(1). 1-16.

28. La Porte, T., Demchak,C., \&de Jong,M.(2002). “Democracy and Bureaucracy in The Age of The Web: Empirical Findings and Theoretical Speculations", Administration and Society, 24 (4)

29. Lele, Gabriel. (2012). The Paradox of Distance in Decentralized Indonesia. Jurnal Ilmu Sosial dan Ilmu Politik. Vol. 15, no 3, Maret.

30. Lonti, Z and Verma,A.(2003). "The Determinant Flexibility and Innovation in The Government Workplace:Recent Evident from Canada", Journal of Public Administation Research and Theory, 13(3),283-310.

31. Moncrieffe,JM. (2001). "Accountability: Idea, Ideal, Constraint", Democratization, $8(3), 26-50$.

32. Prasad, K.G.K.(2002)."Development through Information Technology in Developing Countries: Experiences from an Indian State", The Electronic Journal Information System in Developing Countries, 8(2).

33. Suparman, Nanang. (2017). Kualitas Pelayanan Izin Mendirikan Bangunan (IMB) Pada Badan Pelayanan Perizinan Terpadu Dan Penanaman Modal Kabupaten Cianjur. Borneo dministrator, 13(1).pp.1-88.

34. Vigoda,E.(2000)." Are you being served? The Responsiveness of Public administration to citizens'demands: An empirical examination in Israel. Public Administration, 78(1), 165-191.

35. Zouridis, S.(2002)."From Street-Level to System-Level Bureaucracies: How Information and Communication Technology in Transforming Administrative Discretion and Constitutional Control", Public Administration Review, 62(2).

36. Purbani, Kamalia. 4 Maret 2017. Partisipasi Warga. Pikiran Rakyat, page. 26. 
37. Undang-Undang Republik Indonesia Nomor 32 tahun 2004 Tentang Pemerintahan Daerah

38. Undang-Undang Republik Indonesia Nomor 33 tahun 2004 Tentang Perimbangan Keuangan Antara Pemerintah Pusat Dan Pemerintah Daerah

39. Undang-undang Republik Indonesia Nomor 8 tahun 2005 Tentang Penetapan Perturan Pemerintah Pengganti Undang-Undang Nomor 3 Tahun 2005 Tentang Perubahan Atas Undang-Undang Nomor 32 Tahun 2004.

40. Peraturan Menteri Dalam Negeri Nomor 23 Tahun 2010 Tentang Tata Cara Pelaksanaan Evaluasi Perkembangan Daerah Otonomi Daerah.

41. Peraturan Menteri Dalam Negeri Nomor 43 Tahun 2010 Tentang Perubahan Atas Peraturan Meneteri Dalam Negeri Nomor 31 Tahun 2005 Tentang Petunjuk Teknis Pelaksanaan Tugas Dewan Pertimbangan Otonomi Daerah.

42. Peraturan Pemerintah Nomor 79 Tahun 2005 Tentang Pedoman Pembinaan Dan Pengawasan Penyelenggaraan Pemerintahan Daerah.

43. Undang-Undang Nomor 23 Tahun 2014 Tentang Pemerintahan Daerah

44. Undang-Undang Republik Indonesia Nomor 9 tahun 2015 Tentang Perubahan Kedua Atas Undang-Undang Nomor 23 Tahun 2014 Tentang Pemerintahan Daerah. 